\title{
P082: Beijing and non-Beijing genotypes detection of mycobacterium tuberculosis by melting curve analyzes
}

\author{
Z Tavakoli, A Nazemi \\ From 2nd International Conference on Prevention and Infection Control (ICPIC 2013) \\ Geneva, Switzerland. 25-28 June 2013
}

\section{Introduction}

Tuberculosis is one of the most important infectious diseases in the world today. Rapid diagnosis of drug resistant Mycobacterium tuberculosis (MTB) is critical to starting of an appropriate treatment and preventing of more spread drug resistant MTB strains.

\section{Objectives}

Due to association of Beijing genotype with drug resistance in MTB, we developed a rapid and non-culture method for detection Beijing and non-Beijing MTB in clinical samples.

\section{Methods}

We modified Taqman Real time PCR for detection Beijing and non-Beijing genotypes of Mycobacterium tuberculosis to a free probe method in presence of a single dye together with a melting curve analysis. We then performed a blinded screening with both methods on 33 septum samples from treated tuberculosis patients.

\section{Results}

We were obtained the same results by both methods. Of the 33 patients, 5 samples were Beijing genotype and 28 were non-Beijing genotype. In free probe method, we were clearly identified a melting peak at $81^{\circ} \mathrm{C}$ corresponds to non-Beijing and a melting peak at $88^{\circ} \mathrm{C}$ corresponds to Beijing genotype.

Microbiology, Tonekabon Azad University, Tonekabon, Iran, Islamic Republic Of

\section{Conclusion}

DNA melting curve analysis is a simple and efficient method for the specific detection of amplified products and greatly reduces the cost molecular detection.

\section{Disclosure of interest}

None declared.

Published: 20 June 2013

doi:10.1186/2047-2994-2-S1-P82

Cite this article as: Tavakoli and Nazemi: P082: Beijing and non-Beijing analyzes. Antimicrobial Resistance and Infection Control 2013 2(Suppl 1):P82.

Submit your next manuscript to BioMed Central and take full advantage of:

- Convenient online submission

- Thorough peer review

- No space constraints or color figure charges

- Immediate publication on acceptance

- Inclusion in PubMed, CAS, Scopus and Google Scholar

- Research which is freely available for redistribution 